\title{
Secondary organic aerosol formation from photochemical aging of light-duty gasoline vehicle exhausts in a smog chamber
}

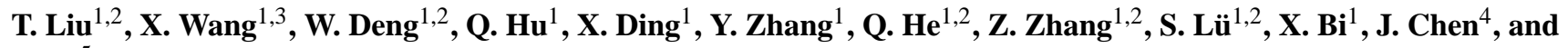 \\ J. $\mathbf{Y u}^{5}$ \\ ${ }^{1}$ State Key Laboratory of Organic Geochemistry, Guangzhou Institute of Geochemistry, Chinese Academy of Sciences, \\ Guangzhou 510640, China \\ ${ }^{2}$ University of Chinese Academy of Sciences, Beijing 100049, China \\ ${ }^{3}$ Guangdong Key Laboratory of Environmental Protection and Resources Utilization, Guangzhou Institute of Geochemistry, \\ Chinese Academy of Sciences, Guangzhou 510640, China \\ ${ }^{4}$ Shanghai Key Laboratory of Atmospheric Particle Pollution and Prevention, Department of Environmental Science \& \\ Engineering, Fudan University, Shanghai 200433, China \\ ${ }^{5}$ Division of Environment, Hong Kong University of Science \& Technology, Clear Water Bay, Kowloon, Hong Kong, China
}

Correspondence to: X. Wang (wangxm@gig.ac.cn)

Received: 9 February 2015 - Published in Atmos. Chem. Phys. Discuss.: 10 April 2015

Revised: 8 July 2015 - Accepted: 4 August 2015 - Published: 14 August 2015

\begin{abstract}
In China, a rapid increase in passenger vehicles has led to the growing concern of vehicle exhaust as an important source of anthropogenic secondary organic aerosol (SOA) in megacities hard hit by haze. In this study, the SOA formation of emissions from two idling light-duty gasoline vehicles (LDGVs) (Euro 1 and Euro 4) operated in China was investigated in a $30 \mathrm{~m}^{3}$ smog chamber. Five photooxidation experiments were carried out at $25^{\circ} \mathrm{C}$ with relative humidity at around $50 \%$. After aging at an $\mathrm{OH}$ exposure of $5 \times 10^{6}$ molecules $\mathrm{cm}^{-3} \mathrm{~h}$, the formed SOA was 12 259 times as high as primary organic aerosol (POA). The SOA production factors (PF) were $0.001-0.044 \mathrm{~g} \mathrm{~kg}^{-1}$ fuel, comparable with those from the previous studies at comparable $\mathrm{OH}$ exposure. This quite lower $\mathrm{OH}$ exposure than that in typical atmospheric conditions might however lead to the underestimation of the SOA formation potential from LDGVs. Effective SOA yields in this study were well fit by a one-product gas-particle partitioning model but quite lower than those of a previous study investigating SOA formation from three idling passenger vehicles (Euro 2-4). Traditional single-ring aromatic precursors and naphthalene could explain $51-90 \%$ of the formed SOA. Unspeciated species such as branched and cyclic alkanes might be the possible precursors for the unexplained SOA. A high-resolution time-offlight aerosol mass spectrometer was used to characterize the
\end{abstract}

chemical composition of SOA. The relationship between $f_{43}$ (ratio of $m / z 43$, mostly $\mathrm{C}_{2} \mathrm{H}_{3} \mathrm{O}^{+}$, to the total signal in mass spectrum) and $\mathrm{f}_{44}$ (mostly $\mathrm{CO}_{2}^{+}$) of the gasoline vehicle exhaust SOA is similar to the ambient semi-volatile oxygenated organic aerosol (SV-OOA). We plot the $\mathrm{O}: \mathrm{C}$ and $\mathrm{H}: \mathrm{C}$ molar ratios of SOA in a Van Krevelen diagram. The slopes of $\Delta \mathrm{H}: \mathrm{C} / \Delta \mathrm{O}: \mathrm{C}$ ranged from -0.59 to -0.36 , suggesting that the oxidation chemistry in these experiments was a combination of carboxylic acid and alcohol/peroxide formation.

\section{Introduction}

The formation mechanisms, magnitude and chemical composition of airborne fine-particulate matter $\left(\mathrm{PM}_{2.5}\right)$ are important to evaluate its effects on human health and climate (Hallquist et al., 2009). Organic aerosol (OA) contributes roughly $\sim 20-50 \%$ of the total fine particle mass at continental midlatitudes (Saxena and Hildemann, 1996; Kanakidou et al., 2005). Atmospheric OA includes primary OA (POA) emitted from sources such as combustion of fossil fuels, biomass burning and volcanic eruptions, and secondary organic aerosol (SOA) formed via gas-particle conversion such as nucleation, condensation, and heterogeneous and multiphase chemistry or the aging of POA (Donahue et al., 2009; 
Jimenez et al., 2009). SOA is ubiquitous and dominates the total OA in various atmospheric environments, accounting for approximately two-thirds of the total OA in urban areas to almost $90 \%$ in urban downwind and rural areas in Northern Hemisphere midlatitudes (Zhang et al., 2007). China, for example, has serious air quality problems due to $\mathrm{PM}_{2.5}$ pollution in the recent decades (Chan and Yao, 2008; Q. Zhang et al., 2012) and SOA contributed $30-90 \%$ of OA mass in its megacities (He et al., 2001; Cao et al., 2003; Duan et al., 2005, 2007; Yang et al., 2005; Hagler et al., 2006). However, models generally underestimate the observed OA levels mainly due to the unclear sources and formation processes of SOA (de Gouw et al., 2005; Heald et al., 2005; Johnson et al., 2006; Volkamer et al., 2006).

Vehicle exhausts emit plenty of primary PM and volatile organic compounds (VOCs) containing precursors of SOA, influencing the near-surface atmospheric chemistry and the air quality, especially in urban areas. SOA formation from diesel generators and vehicles has been widely studied in smog chambers, demonstrating that the SOA mass formed from the exhaust of diesel generators and medium-, and heavy-duty diesel vehicles (HDDVs) usually exceeds the mass of emitted POA (Robinson et al., 2007; Weitkamp et al., 2007; Chirico et al., 2010; Miracolo et al., 2010; Samy and Zielinska, 2010; Nakao et al., 2011; Kroll et al., 2012). However, there are few studies on the SOA formation from gasoline vehicle exhausts. Nordin et al. (2013) investigated SOA formation from idling gasoline exhausts from three passenger vehicles (Euro 2-4), finding that $\mathrm{C}_{6}-\mathrm{C}_{9}$ light aromatics contributed up to $60 \%$ of the formed SOA. While Platt et al. (2013) estimated aromatic precursors including $\mathrm{C}_{6}-$ $\mathrm{C}_{10}$ light aromatics and naphthalene were responsible for less than $20 \%$ of the SOA formed from the aging of emissions from a Euro 5 gasoline car operated during a New European Driving Cycle. To exclude the influence of a small sample size, Gordon et al. (2014) studied aging of emissions from 15 light-duty gasoline vehicles with model years ranging from 1987 to 2011, concluding that traditional precursors could fully explain the SOA from older vehicles and unspeciated organics were responsible for the majority of the SOA from the newer vehicles. Therefore, chemical compositions of SOA formed from gasoline vehicle exhaust varied a lot among vehicles of different types, model years and operating conditions.

In China, the number of light-duty gasoline vehicles (LDGVs) reached 98.8 million in 2012, increasing at a rate of approximately $20 \%$ per year since 2005 (NBSC, 2013). Furthermore, gasoline fuel in China has a relatively higher mass content of alkenes and aromatic hydrocarbons than in the USA (Schauer et al., 2002; Zhang et al., 2013), and current emission standards of LDGVs in China lag behind European countries and the USA. The emission factors of $\mathrm{PM}_{2.5}$, organic carbon (OC), element carbon (EC), $\mathrm{NO}_{x}, \mathrm{SO}_{2}, \mathrm{NH}_{3}$ and nonmethane hydrocarbons (NMHCs) for on-road vehicles in China were quite different from those in other coun- tries (Liu et al., 2014; Y. L. Zhang et al., 2015). Therefore, it is urgent to investigate the SOA formation from vehicle exhaust in China to help make suitable policies to mitigate air pollution and also to provide valuable parameters to chemical transport models.

Here, we directly introduced dilute emissions from two idling LDGVs operated in China to a smog chamber to investigate the SOA formation. The magnitude and composition of the SOA formed from gasoline vehicle exhaust and whether traditional SOA precursors can explain the formed SOA was evaluated and discussed in this paper.

\section{Materials and methods}

\subsection{Experimental setup}

The photochemical aging experiments were carried out in the smog chamber of the Guangzhou Institute of Geochemistry, Chinese Academy of Sciences (GIG-CAS). The GIG-CAS smog chamber has a $30 \mathrm{~m}^{3}$ fluorinated ethylene propylene (FEP) reactor housed in a temperature-controlled room. Details of setup and facilities about the chamber have been described elsewhere (Wang et al., 2014). Briefly, black lamps (1.2 m long, 60 W Philips/10R BL, Royal Dutch Philips Electronics Ltd, the Netherlands) are used as light source, providing a $\mathrm{NO}_{2}$ photolysis rate of $0.49 \mathrm{~min}^{-1}$. Two Teflon-coated fans are installed inside the reactor to guarantee proper mixing of the introduced gas species and particles within $120 \mathrm{~s}$. Temperature can be set in the range from -10 to $40^{\circ} \mathrm{C}$ with an accuracy of $\pm 1^{\circ} \mathrm{C}$ and is measured by eight temperature sensors inside the enclosure and one just inside the reactor. Relative humidity $(\mathrm{RH})$ inside the reactor is achieved by vaporizing Milli-Q ultrapure water contained in a $0.5 \mathrm{~L}$ Florence flask and then flushing the water vapor into the reactor with purified dry air until target RH is reached. In the present study, temperature and RH inside the reactor were all set to $25^{\circ} \mathrm{C}$ and $50 \%$, respectively. During the experiments, the top frame is automatically lowered to maintain a differential positive pressure inside the reactor against the enclosure to avoid the contamination of the enclosure air.

Gasoline vehicle exhausts were injected to the reactor through Teflon lines using two oil-free pumps (Gast Manufacturing, Inc, USA) at a flow rate of $40 \mathrm{~L} \mathrm{~min}^{-1}$. The injection time varied from a few minutes to more than $1 \mathrm{~h}$ based on the primary emissions of different vehicles. A schematic of the smog chamber and the vehicle exhaust injection system is shown in Fig. 1.

\subsection{Characterization of gas- and particle-phase chemical compositions and particle sizes}

Gas-phase ozone $\left(\mathrm{O}_{3}\right)$ and $\mathrm{NO}_{x}$ were measured online with dedicated monitors (EC9810 and 9841T, Ecotech, Australia). Online monitoring of parent VOCs such as $\mathrm{C}_{6-}$ $\mathrm{C}_{10}$ single-ring aromatic hydrocarbons and their oxidation 


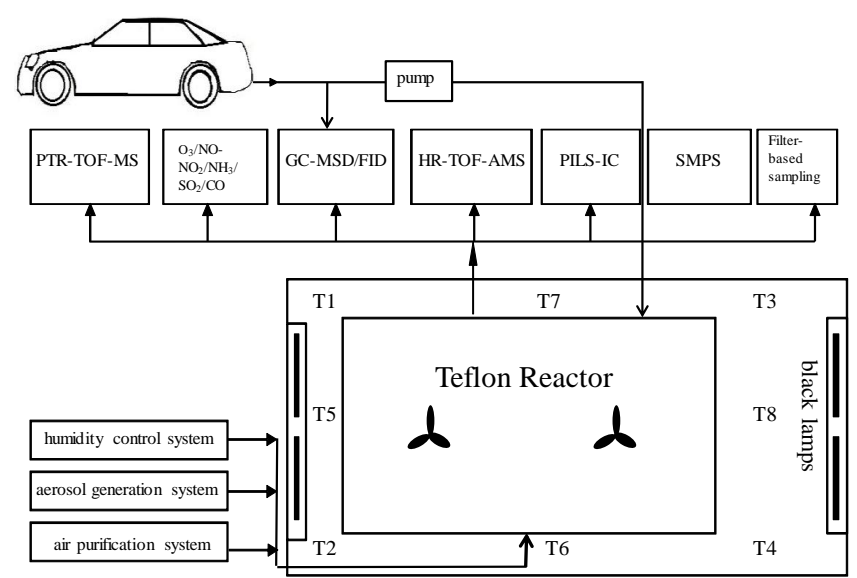

Figure 1. Schematic of the GIG-CAS smog chamber facility and vehicle exhaust injection system.

products were available with a commercial proton-transferreaction time-of-flight mass spectrometer (PTR-TOF-MS; Model 2000, Ionicon Analytik GmbH, Austria). Detailed descriptions of the PTR-TOF-MS technique can be found elsewhere (Lindinger et al., 1998; Jordan et al., 2009). In this study the decay curve of toluene measured by PTR-TOF-MS were also used to derive the average hydroxyl radical $(\mathrm{OH})$ concentration during each experiment. A wide spectrum of VOCs were also measured offline by drawing $250 \mathrm{ml}$ of air inside the reactor to a Model 7100 Preconcentrator (Entech Instruments Inc., USA) coupled with an Agilent 5973N gaschromatography mass-selective detector/flame ionization detector (GC-MSD/FID; Agilent Technologies, USA). Detailed descriptions of the method can be found elsewhere (Wang and Wu, 2008; Zhang et al., 2010; Y. Zhang et al., 2012, 2013). $\mathrm{C} 2$ and $\mathrm{C} 3$ and $\mathrm{C} 4-\mathrm{C} 12$ hydrocarbons were measured by GC-FID and GC-MSD, respectively. In this study, the offline measurement was the standard method to determine the mass concentrations of VOCs. PTR-TOF-MS was used for deriving the time-resolved concentrations of VOCs. The VOC concentrations measured offline were also used as an independent check of that measured online by the PTRTOF-MS. To determine $\mathrm{CO} / \mathrm{CO}_{2}$ concentrations before and after the introduction of exhausts, air samples were also collected into $2 \mathrm{~L}$ cleaned Teflon bags. $\mathrm{CO}$ was analyzed using gas chromatography (Agilent 6980GC, USA) with a flame ionization detector and a packed column (5A molecular sieve $60 / 80$ mesh, $3 \mathrm{~m} \times 1 / 8$ in.) (Y. Zhang et al., 2012), and $\mathrm{CO}_{2}$ was analyzed with an HP 4890D gas chromatograph (Yi et al., 2007). The detection limits of $\mathrm{CO}$ and $\mathrm{CO}_{2}$ were $<30 \mathrm{ppb}$. The relative standard deviations (SDs) were all less than $3 \%$ based on seven duplicates running $1.0 \mathrm{ppm} \mathrm{CO}$ and $\mathrm{CO}_{2}$ standards (Spectra Gases Inc, USA).

A high-resolution time-of-flight aerosol mass spectrometer (HR-TOF-MS; Aerodyne Research Incorporated, USA) was used to measure the particle chemical compositions
(Jayne et al., 2000; DeCarlo et al., 2006). The instrument was operated in the high sensitivity $\mathrm{V}$ mode and high resolution $\mathrm{W}$ mode alternatively every $2 \mathrm{~min}$. The toolkit Squirrel $1.51 \mathrm{H}$ was used to obtain time series of various mass components (sulfate, nitrate, ammonium and organics). We used the toolkit Pika $1.1 \mathrm{H}$ to determine the average element ratios of organics, like $\mathrm{H}: \mathrm{C}, \mathrm{O}: \mathrm{C}$, and $\mathrm{N}: \mathrm{C}$ (Aiken et al., 2007, 2008). The contribution of gas-phase $\mathrm{CO}_{2}$ to the $m / z 44$ signal was corrected using the measured $\mathrm{CO}_{2}$ concentrations. The HR-TOF-MS was calibrated using $300 \mathrm{~nm}$ of monodisperse ammonium nitrate particles.

Particle number/volume concentrations and size distributions were measured with a scanning mobility particle sizer (SMPS; TSI Incorporated, USA., classifier model 3080, CPC model 3775). Flow rates of sheath and aerosol flow were 3.0 and $0.3 \mathrm{~L} \mathrm{~min}^{-1}$, respectively, allowing for size distribution scanning ranging from 14 to $700 \mathrm{~nm}$ within $255 \mathrm{~s}$. The accuracy of the particle number concentration is $\pm 10 \%$. An aerosol density of $1.4 \mathrm{~g} \mathrm{~cm}^{-3}$ was assumed to convert the particle volume concentration into the mass concentration (Zhang et al., 2005). Conductive silicon tubes were used as sampling lines for HR-TOF-MS and SMPS to reduce electrostatic losses of particles.

\subsection{Experimental procedure}

Two light-duty gasoline-powered vehicles were used in this study, one Euro 1 vehicle and one Euro 4 vehicle. They are both port fuel injected vehicles. More details of the vehicles are listed in Table 1. Both of the vehicles were fueled with Grade 93 gasoline, which complies with the Euro III gasoline fuel standard. Details of the oil compositions can be found in our previous study (Zhang et al., 2013).

Prior to each experiment, the reactor was evacuated and filled with purified dry air at least 5 times, then the reactor was flushed with purified dry air for at least $48 \mathrm{~h}$ until no residual hydrocarbons, $\mathrm{O}_{3}, \mathrm{NO}_{x}$, or particles were detected in the reactor to avoid carry-over problems from day-to-day experiments. Prior to the introduction of exhaust, the temperature control system and Teflon-coated fans were turned on. The exhaust could be injected when the temperature in the reactor was stable at the set temperature of $25^{\circ} \mathrm{C}$.

The LDGV was parked outside the laboratory and tested while idling. Before the injection of exhaust, the cars were idling for at least half an hour to warm up the three-way catalysts, and then the vehicle exhausts were injected into the reactor. During their introduction, the raw exhausts were also sampled in $8 \mathrm{~L}$ cleaned aluminum foil bags by a mechanical pump with a flow rate of about $5 \mathrm{~L} \mathrm{~min}^{-1}$. VOCs and $\mathrm{CO}_{2}$ in these samples were measured offline by the same methods mentioned above to characterize the primary emissions from the exhaust pipe. The exhaust in the reactor was diluted by a factor of 13-30 compared to the tailpipe.

Additional $\mathrm{NO}$ was then added to adjust the $\mathrm{VOC} / \mathrm{NO}_{x}$ ratios to around 10.0 or 2.0 (Table 2), within the range of 0.5 
Table 1. Detailed information of the two light-duty gasoline vehicles.

\begin{tabular}{cccccccc}
\hline ID & $\begin{array}{c}\text { emission } \\
\text { standard class }\end{array}$ & vehicle & $\begin{array}{c}\text { model } \\
\text { year }\end{array}$ & $\begin{array}{c}\text { mileage } \\
(\mathrm{km})\end{array}$ & $\begin{array}{c}\text { displacement } \\
\left(\mathrm{cm}^{3}\right)\end{array}$ & $\begin{array}{c}\text { power } \\
(\mathrm{kW})\end{array}$ & $\begin{array}{c}\text { weight } \\
(\mathrm{kg})\end{array}$ \\
\hline I & Euro 4 & Golf & 2011 & 25000 & 1598 & 77 & 1295 \\
II & Euro 1 & Accord & 2002 & 237984 & 2298 & 110 & 1423 \\
\hline
\end{tabular}

10 reported in gasoline vehicle exhaust tests and downwind of urban areas (Clairotte et al., 2013). The initial concentrations of $\mathrm{NO}_{x}$ at the start of the experiments ranged from 134 to $956 \mathrm{ppb}$. In each experiment $\mathrm{CH}_{3} \mathrm{CN}$ was used as an indicator of dilution in the reactor. After being characterized in the dark for more than $30 \mathrm{~min}$, the exhaust was exposed to black light continuously for $5 \mathrm{~h}$. After the black lamps were switched off, the formed SOA was characterized for another $2-3 \mathrm{~h}$ to correct the particle wall loss. Blank experiments with no vehicle exhaust introduced were performed to quantify the reactivity of the matrix gas. After $5 \mathrm{~h}$ of irradiation, the number and mass of formed particles were $<5 \mathrm{~cm}^{-3}$ and $0.1 \mu \mathrm{g} \mathrm{m}^{-3}$, respectively.

During the introduction of exhausts, particles and VOCs might deposit to the surface of the transfer lines. Therefore, a flow rate of as high as $20 \mathrm{~L} \mathrm{~min}^{-1}$ and a transfer line of as short as $5 \mathrm{~m}$ were used to provide residence time within seconds and thus reduce the losses of particles and VOCs in the transfer lines. Furthermore, before being introduced into the reactor, exhausts were generally pumped through the transfer lines for half an hour to saturate the transfer lines with particles and VOCs while warming the catalytic converter. Losses of particles and VOCs in the introduction lines were determined by comparing the concentrations of total particle number and VOCs in the directly emitted exhausts with the ones after passing through the transfer lines. The loss of total particle number was estimated to be less than $3 \%$. The penetration efficiency of particles due to diffusion in a cylindrical tube, $\eta\left(d_{\mathrm{p}}\right)$, can also be estimated by a laminar diffusional deposition model (Gormley and Kennedy, 1949). For particles with diameters larger than $10 \mathrm{~nm}$, the penetration efficiency was higher than $95 \%$, indicating minor losses of particles in the transfer line. The losses of VOCs in the transfer line were estimated to be less than $5 \%$, which might lead to a small underestimation of SOA production.

\subsection{Data analysis}

\subsubsection{Wall-loss corrections}

The loss of particles and organic vapors to the reactor walls has to be accounted for to accurately quantify the SOA formation. The loss of particles onto the walls has been well constrained and is treated as a first-order process (McMurry and Grosjean, 1985). The wall-loss rate constant was determined separately for each experiment by fitting the SMPS and aerosol mass spectrometer (AMS) data with first-order kinetics when UV lamps were turned off. By applying this rate to the entire experiment, we use the same method as Pathak et al. (2007), treating the particle wall loss as a firstorder process to correct the wall loss of the particles. The wall loss of particles is a size-dependent process; therefore, the influence of nucleation needs to be examined due to the rapid loss of nucleation mode particles. In this study, the impact of the nucleation event on wall-loss estimate is considered to be negligible for only less than $3 \%$ of the particle mass is in the nucleation mode 10 min after nucleation for all the experiments (Fig. S1 in the Supplement). In general, the loss of condensable organic vapors to the walls is estimated for two limiting cases (Weitkamp et al., 2007; Hildebrandt et al., 2009). In the first case (designated $\omega=0$ ), no organic vapors is lost to the walls (only to suspended particles). In the second case (designated $\omega=1$ ), the particles on the walls are in equilibrium with the organic vapors; therefore, condensation to the particles on the walls is identical to the suspended particles. We use the $\omega=0$ wall-loss correction assuming the organic vapors' only condensation onto suspended particles. The $\omega=1$ wall-loss correction is not suitable for the experiments here in which nucleation occurred and no seed particles were added (Henry et al., 2012).

\subsubsection{AMS data corrections}

Theoretically, the sum of the PM mass measured by AMS should be equal to the mass calculated from the SMPS mass size distributions. However, both methods have limitations. One must assume a particle shape and density to convert the volume concentration measured by SMPS to the mass concentration. Here, we assume that particles are spherical with an average density of $1.4 \mathrm{~g} \mathrm{~cm}^{-3}$ (Zhang et al., 2005). Fractal-like particles will cause the overestimate of the spherical equivalent diameter, thus overestimating the particle mass. AMS tends to underestimate the PM mass due to the transmission efficiency (Liu et al., 2007) and the AMS collection efficiency (Gordon et al., 2014), leading to the discrepancy between the AMS data and SMPS data. Figure S2 shows the particle volume distribution measured by SMPS for a typical smog chamber experiment (experiment 2). Most particles were in the range $40-120 \mathrm{~nm}$ after SOA formation. Since the transmission window of the standard lens of HRTOF-AMS is $60-600 \mathrm{~nm}$ (aerodynamic diameter) (Liu et al., 2007), particles with diameter smaller than $40 \mathrm{~nm}$ (mobility diameter) were cut from the lower edge of the volume distri- 
Table 2. Initial conditions for the light-duty gasoline vehicle photo-oxidation experiments.

\begin{tabular}{cccccccc}
\hline Experiment & $\begin{array}{c}\text { vehicle } \\
\text { ID }\end{array}$ & $\begin{array}{c}\mathrm{T} \\
\left({ }^{\circ} \mathrm{C}\right)^{\mathrm{a}}\end{array}$ & $\begin{array}{c}\mathrm{RH} \\
(\%)^{\mathrm{a}}\end{array}$ & $\mathrm{VOC} / \mathrm{NO}_{x}$ & $\begin{array}{c}\mathrm{VOCs} \\
(\mathrm{ppbv})^{\mathrm{b}}\end{array}$ & $\begin{array}{c}\mathrm{NO} \\
(\mathrm{ppbv})\end{array}$ & $\begin{array}{c}\mathrm{NO}_{2} \\
(\mathrm{ppbv})\end{array}$ \\
\hline 1 & I & $25.8 \pm 0.7$ & $52.0 \pm 1.8$ & 10.2 & 1368 & 115.1 & 18.4 \\
2 & II & $24.1 \pm 0.6$ & $57.0 \pm 2.0$ & 6.0 & 2583 & 431.0 & 0.6 \\
3 & I & $25.0 \pm 0.8$ & $52.9 \pm 2.0$ & 9.3 & 2896 & 300.6 & 9.5 \\
4 & I & $24.2 \pm 0.8$ & $52.5 \pm 2.7$ & 2.0 & 1885 & 794.1 & 161.9 \\
5 & II & $25.0 \pm 0.3$ & $52.6 \pm 1.3$ & 7.2 & 1507 & 210.4 & 0.7 \\
\hline
\end{tabular}

${ }^{a}$ Stated uncertainties $(1 \sigma)$ are from scatter in temperature and relative humidity, respectively. ${ }^{\mathrm{b}} \mathrm{C} 2$ and $\mathrm{C} 3$ and $\mathrm{C} 4-\mathrm{C} 12$ hydrocarbons were measured by GC-FID and GC-MSD, respectively.

bution. One hour after nucleation occurred, only $<5 \%$ of the mass was outside the transmission window of HR-TOF-MS, indicating that HR-TOF-AMS might underestimate the PM in the early stage of SOA formation. In this study, we use the same method as Gordon et al. (2014) to correct the AMS data.

For all the experiments with discrepancies between the AMS and SMPS data (Fig. S3), we assume that the difference in mass has the same composition as the measured components. We then calculate scaling factors, $\mathrm{AMS}_{\mathrm{sf}}$, to correct the PM mass measured by AMS and make it accordant with the SMPS measurements. The scaling factor is

$\mathrm{AMS}_{\mathrm{sf}}=\frac{C_{\mathrm{SMPS}}}{C_{\mathrm{Org}}+C_{\mathrm{SO}_{4}}+C_{\mathrm{NO}_{3}}+C_{\mathrm{NH}_{4}}}$,

where $C_{\text {SMPS }}$ is the total particle mass concentration derived by the SMPS, $C_{\mathrm{Org}}, C_{\mathrm{SO}_{4}}, C_{\mathrm{NO}_{3}}$ and $C_{\mathrm{NH}_{4}}$ are the mass concentrations of organics, sulfate, nitrate and ammonium measured by the AMS. As shown in Fig. S3, the mass of primary particles measured by SMPS was comparable with that measured by HR-TOF-AMS; thus, we assumed that the mass of black carbon (BC) in the reactor was negligible. The $\mathrm{AMS}_{\mathrm{Sf}}$ for each time step after nucleation is calculated and used to scale the AMS data for the entire experiment.

\subsubsection{Effective SOA yields}

To compare the SOA formation with other studies, we calculated effective SOA yields for all experiments. The effective SOA yield Y was defined as the ratio of the wall-losscorrected SOA mass to the mass of reacted organic precursors (Odum et al., 1996, 1997; Donahue et al., 2006). In this study, reacted organic precursors included in calculation are only those quantified by GC-MSD, including benzene, toluene, $C_{2}$-benzene, $C_{3}$-benzene, $C_{4}$-benzene and naphthalene. A detailed list of these compounds is presented in Table S2. At the beginning and end of each experiment, air samples in the reactor were collected into $2 \mathrm{~L}$ electropolished and evacuated stainless steel canisters and analyzed by GC-MSD to determine the mass of reacted organic precursors.

\subsubsection{Emission factors}

Emission factor (EF) of a pollutant $P$ is calculated on a fuel basis $\left(\mathrm{g} \mathrm{kg}^{-1}\right)$ :

$\mathrm{EF}=10^{3} \cdot[\Delta P] \cdot\left(\frac{\mathrm{MW}_{\mathrm{CO}_{2}}}{\left[\Delta \mathrm{CO}_{2}\right]}+\frac{\mathrm{MW}_{\mathrm{CO}}}{[\Delta \mathrm{CO}]}+\frac{\mathrm{MW}_{\mathrm{HC}}}{[\Delta \mathrm{HC}]}\right) \cdot \frac{\omega_{\mathrm{C}}}{\mathrm{MW}_{\mathrm{C}}}$,

where $[\Delta P],\left[\Delta \mathrm{CO}_{2}\right],[\Delta \mathrm{CO}]$, and $[\Delta \mathrm{HC}]$ are the background corrected concentrations of $P, \mathrm{CO}_{2}, \mathrm{CO}$ and the total hydrocarbons in the reactor (in $\mu \mathrm{g} \mathrm{m}^{-3}$ ); $\mathrm{MW}_{\mathrm{CO}_{2}}, \mathrm{MW}_{\mathrm{CO}}$, $\mathrm{MW}_{\mathrm{HC}}$, and $\mathrm{MW}_{\mathrm{C}}$ are the molecular weights of $\mathrm{CO}_{2}, \mathrm{CO}$, $\mathrm{HC}$ and $\mathrm{C} . \omega_{C}(0.85)$ is the carbon intensity of the gasoline (Kirchstetter et al., 1999).

\subsubsection{Determination of $\mathrm{OH}$ exposure}

Decay of toluene measured by PTR-TOF-MS is used to derive the average $\mathrm{OH}$ concentration during each experiment. Changes in the toluene concentration over time can be expressed as

$\frac{\mathrm{d}[\text { toluene }]}{\mathrm{d} t}=-k \cdot[\mathrm{OH}] \cdot[$ toluene $]$,

where $k$ is the rate constant for the reaction between toluene and $\mathrm{OH}$ radical. Assuming a constant $\mathrm{OH}$ concentration during an experiment, we can integrate Eq. (3) to get Eq. (4):

$\ln \left(\frac{[\text { toluene }]_{0}}{[\text { toluene }]_{t}}\right)=k \cdot[\mathrm{OH}] \cdot t$.

So, by plotting $\ln \left([\text { toluene }]_{0} /[\text { toluene }]_{t}\right)$ vs. time $t$, we can obtain a slope that equals $k \times[\mathrm{OH}]$. The average $\mathrm{OH}$ concentration is therefore calculated as

$[\mathrm{OH}]=\frac{\text { slope }}{k}$.

The $\mathrm{OH}$ exposure is then determined through multiplying the average $\mathrm{OH}$ concentration by time.

\section{Results and discussion}

\subsection{VOC composition}

Figure 2 shows the average composition of gasoline vehicle exhausts from vehicle I (Euro 4) and II (Euro 1). For Euro 4 
and 1 vehicles, alkanes contributed about 42.9 and $66.2 \%$ of the total speciated VOCs measured with the GC-FID/MSD by mass, respectively, dominating the speciated VOC emissions in gasoline vehicle exhausts. Due to the high concentrations of isopentane and methylpentane, branched alkanes contributed approximately $44.9 \%$ of the total VOCs for the Euro 1 vehicle, quite higher than that for the Euro 4 vehicle $(23.3 \%)$. Aromatic hydrocarbons accounted for about 38.0 and $22.5 \%$ of the total VOCs for Euro 4 and 1 vehicles, respectively, relatively higher than the $10-15 \%$ observed by Nordin et al. (2013) for idling Euro 2, 3 and 4 vehicles. The mass fraction of aromatic hydrocarbons for the Euro 4 vehicle was comparable with $32.2 \%$ for idling private cars in Hong Kong (Guo et al., 2011) and $38.3 \%$ for Euro 3 lightduty gasoline vehicles operated through ECE cycles with an average speed around $18.7 \mathrm{~km} \mathrm{~h}^{-1}$ (Wang et al., 2013). Both Schauer et al. (2002) and Gentner et al. (2013) observed that aromatic hydrocarbons contributed around $27 \%$ of the total VOCs for gasoline-powered automobiles driven through the cold-start Federal Test Procedure urban driving cycle and onroad gasoline vehicles in the Caldecott tunnel, similar to that of the Euro 1 vehicle. Recently, Huang et al. (2015) reported that mass fractions of aromatic hydrocarbons were as high as $46.4 \%$ for Euro 1, 2, and 3 light-duty gasoline vehicles operated through ECE cycles. Therefore, the variations of the composition of LDGV exhausts in this study were within the range of previous studies.

The averaged emission factors of VOCs and aromatic hydrocarbons for the Euro 4 vehicle were 2.1 and $0.8 \mathrm{~g} \mathrm{~kg}^{-1}$, approximately 26.0 and $43.5 \%$ of those for the Euro 1 vehicle, respectively. Compared with a Euro 5 gasoline vehicle operated during a New European Driving Cycle, the emission factor of VOCs for the Euro 4 vehicle was about 1.7 times higher (Platt et al., 2013). Using $12.7 \mathrm{~km} \mathrm{~L}^{-1}$ as the average fuel efficiency (Wagner et al., 2009), we obtained the VOC emission factors based on grams per kilometer for Euro 4 and 1 vehicles to be 0.12 and $0.46 \mathrm{~g} \mathrm{~km}^{-1}$, respectively, comparable with the previous reported values for Euro 1 and 4 gasoline vehicles in China (Huo et al., 2012; Huang et al., 2015). According to previous studies, there is a clear reduction of VOC emissions from gasoline vehicles with stricter emission standards (Huo et al., 2012; Huang et al., 2015). It is worth noting that emissions of HC from gasoline vehicles during idling were observed to be lower than those in the acceleration and deceleration modes (Tong et al., 2000; Yamamoto et al., 2012; Huang et al., 2013), but in a similar level with those in the cruising mode (Tong et al., 2000). It is important to note that the reported data are only based on five chamber experiments with two LDGVs under idling conditions. More tests are needed to assess SOA formation from gasoline vehicle exhausts in China.

\subsection{SOA formation}

Figure 3 shows the temporal evolution of gas-phase and particle-phase species during a typical smog chamber experiment. During the period -1.3 to $-0.85 \mathrm{~h}$, the vehicle exhausts were introduced into the reactor. At time $-0.55 \mathrm{~h}$, the relative humidity was adjusted to approximately $40 \%$ and HR-TOF-AMS was connected to characterize the primary $\mathrm{PM}$. NO was injected to adjust the $\mathrm{VOC} / \mathrm{NO}_{x}$ ratio at the approximate time of $-0.25 \mathrm{~h}$. After the black lamps were turned on, $\mathrm{NO}$ was fast converted to $\mathrm{NO}_{2}$ in less than $1 \mathrm{~h}$ and then $\mathrm{O}_{3}$ was accumulated and $\mathrm{OH}$ radicals were formed. When NO concentration decreased to a low level of about 5 ppb, gas-phase light aromatics, especially $C_{3}$-benzene with higher reactivity, decayed rapidly due to the reaction with the $\mathrm{OH}$ radical. SOA was thus rapidly formed and increased to a high level in less than $2 \mathrm{~h}$. As shown in Table 3, at the end of all the experiments, the formed SOA was 12-259 times as high as POA. This enhancement is consistent with 9500 times increase recently reported by Nordin et al. (2013) when studying SOA formation from idling European gasoline passenger vehicle emissions. As shown in Fig. 3c, the total particle number concentration increased fast from 82 to $116143 \mathrm{~cm}^{-3}$, indicating dramatic new particle formation, which might be due to the starting surface concentrations of particles being below a critical value $\left(100-2000 \mu \mathrm{m}^{2} \mathrm{~cm}^{-3}\right.$; Table S1) (Wehner et al., 2004). As shown in Table S1, primary particle numbers in the reactor in this study ranged from 82 to $18948 \mathrm{~cm}^{-3}, 1-2$ orders of magnitude higher than that of a Euro 2 car operated at idling with a similar dilution ratio (Nordin et al., 2013), indicating that the small starting particle number concentrations might mainly be due to the idling condition of tested cars rather than the losses in the introduction lines. In addition, upon entering into the chamber, emitted particles would partition due to dilution, as in the atmosphere, regardless of the temperature and concentration in the sampling system, which might lead to the decrease of starting number concentrations. A certain extent of primary particles under the detection limit of $14 \mathrm{~nm}$ of SMPS also contributed to the measured small starting number concentration of particles.

Deposition of SOA-forming vapors on the walls might lead to the underestimation of SOA production. The wall-loss rate coefficient of vapors is related to the numbers of carbon and oxygen in the molecule (X. Zhang et al., 2015). Here, we take $\mathrm{C}_{7} \mathrm{H}_{8} \mathrm{O}_{4}$, a product of the photo-oxidation of toluene, as an example. The loss of $\mathrm{C}_{7} \mathrm{H}_{8} \mathrm{O}_{4}$ to walls would be $7 \%$ in an hour before SOA formation when a wall-deposition rate of $2 \times 10^{-5} \mathrm{~s}^{-1}$ was used (X. Zhang et al., 2015). After SOA formation, the surface concentrations of particles increased fast to as high as $2000 \mu \mathrm{m}^{2} \mathrm{~cm}^{-3}$ in an hour, which would reduce the vapor wall losses.

SOA production factors (PFs) for the LDGVs tested in this study were estimated to vary from 0.001 to $0.044 \mathrm{~g} \mathrm{~kg}^{-1}$ fuel, within the results of Nordin et al. (2013) 
Table 3. Summary of the results for the light-duty gasoline vehicle photo-oxidation experiments.

\begin{tabular}{ccccccc}
\hline Experiment & $\begin{array}{c}\text { vehicle } \\
\text { ID }\end{array}$ & $\begin{array}{c}\text { OH } \\
\left(\times 10^{6} \text { molecules cm }^{-3}\right)\end{array}$ & $\begin{array}{c}\text { POA } \\
\left(\mu \mathrm{g} \mathrm{m}^{-3}\right)\end{array}$ & $\begin{array}{c}\text { SOA } \\
\left(\mu \mathrm{g} \mathrm{m}^{-3}\right)\end{array}$ & $\begin{array}{c}\text { SOA/POA } \\
\text { effective } \\
\text { yield }\end{array}$ \\
\hline 1 & I & 1.23 & 1.1 & 51.1 & 46 & 0.103 \\
2 & II & 0.73 & 0.2 & 17.6 & 88 & 0.038 \\
3 & I & 0.88 & 0.3 & 77.6 & 259 & 0.119 \\
4 & I & 1.20 & 1.0 & 125.4 & 125 & 0.172 \\
5 & II & 0.79 & 0.3 & 4.0 & 12 & 0.028 \\
\hline
\end{tabular}
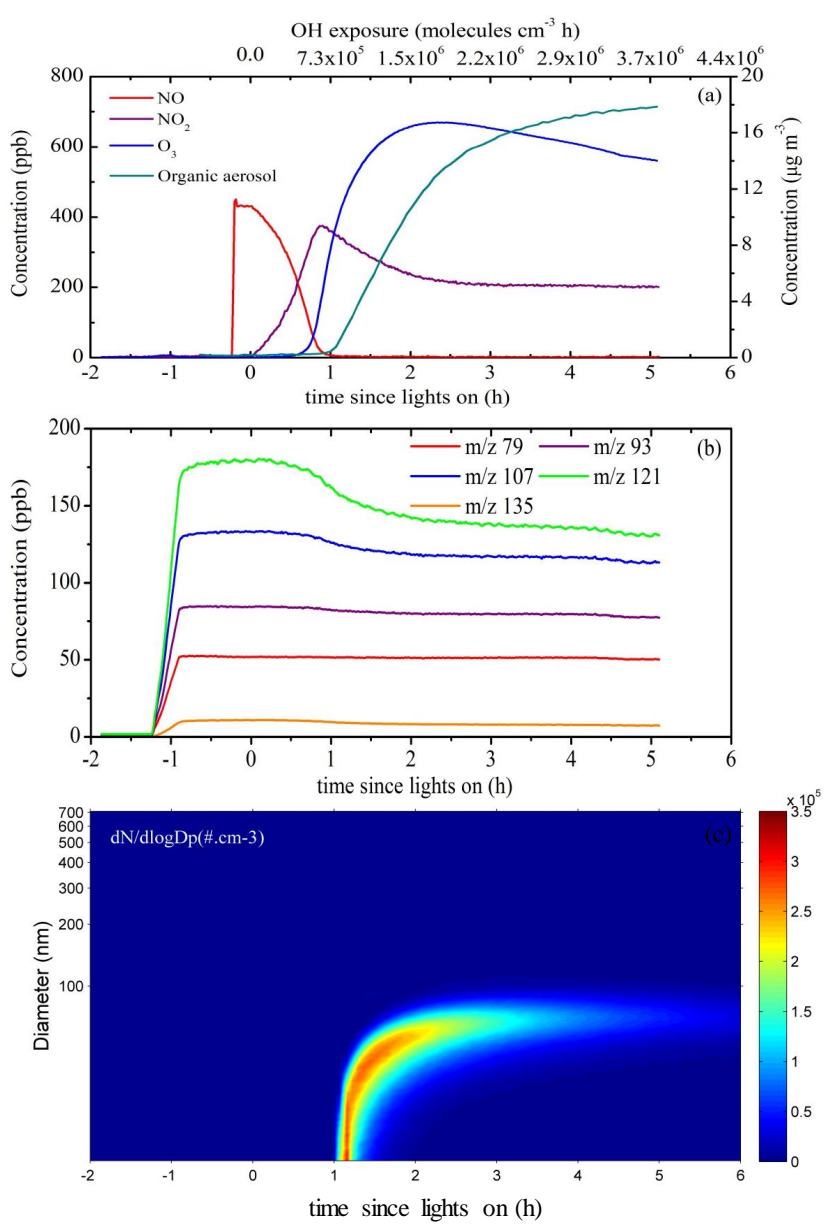

Figure 2. Concentration-time plots of gas-phase and particle-phase species and particle number concentration distribution as a function of time during a typical smog chamber experiment (experiment 2): (a) $\mathrm{NO}, \mathrm{NO}_{2}, \mathrm{O}_{3}$ (left $y$ axis) and organic aerosol (right $y$ axis); (b) gas-phase light aromatics (measured by PTR-TOF-MS) (benzene characterized by $m / z$ 79; toluene characterized by $m / z$ 93; $C_{2}$-benzene characterized by $m / z \quad 107 ; C_{3}$-benzene characterized by $\mathrm{m} / \mathrm{z} 121 ; C_{4}$-benzene characterized by $\mathrm{m} / \mathrm{z} 135$ ); (c) particle size-number concentration distributions as a function of time. The vehicle exhaust was introduced into the reactor between -1.3 and $-0.85 \mathrm{~h}$; the primary emissions were characterized from -0.85 to $0 \mathrm{~h}$; at time $0 \mathrm{~h}$, the black lamps were turned on.
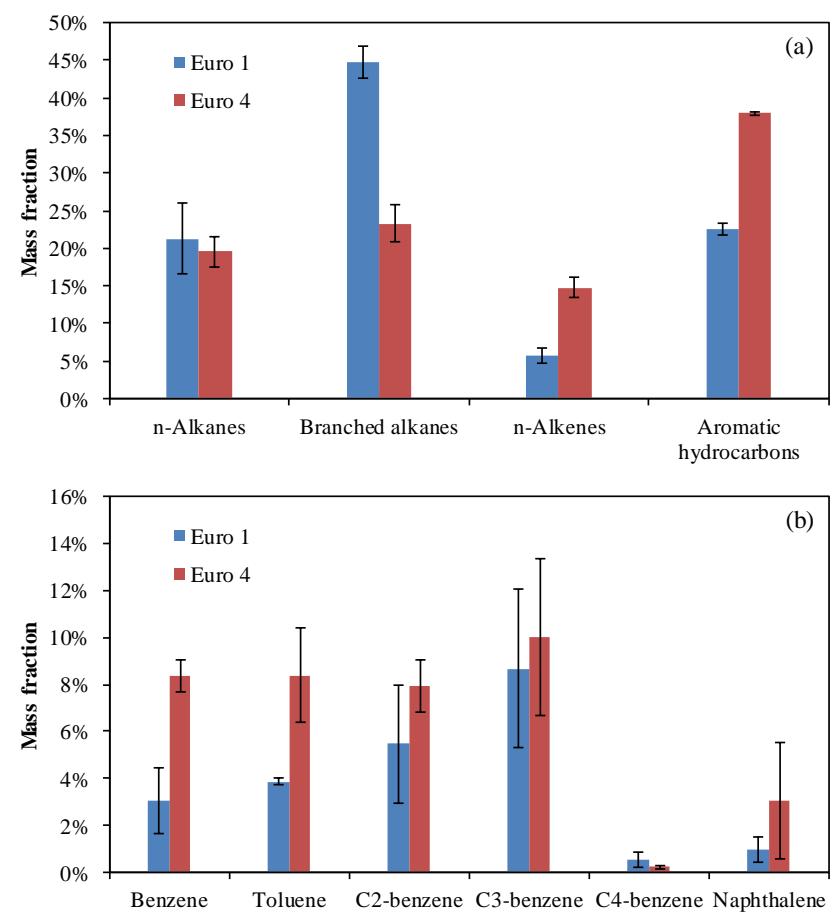

Figure 3. Composition of (a) VOCs and (b) aromatics of gasoline vehicle exhausts from Euro 1 and Euro 4 private cars, presented as weight percentage of speciated VOCs. C2 and C3 and C4-C12 hydrocarbons were measured by GC-FID and GC-MSD, respectively. The error bars $(1 \sigma)$ represent variability from measurements for each vehicle.

and Gordon et al. (2014) with $\mathrm{OH}$ exposure of around $5.0 \times 10^{6}$ molecules $\mathrm{cm}^{-3} \mathrm{~h}$. A recent study investigating SOA formation from in-use vehicle emissions in a highway tunnel in Pittsburgh indicated that the peak SOA production was measured at an $\mathrm{OH}$ exposure of $1.9 \times 10^{8}$ molecules $\mathrm{cm}^{-3} \mathrm{~h}$ and current smog chamber studies may underestimate the ultimate SOA production by a maximum factor of about 10 due to the limited $\mathrm{OH}$ exposure (Tkacik et al., 2014). 
The average $\mathrm{OH}$ radical concentration (Table 3 ) was determined to be $0.79-1.23 \times 10^{6}$ molecules $\mathrm{cm}^{-3}$ during our experiments. This $\mathrm{OH}$ level was about 10 times lower than the average $\mathrm{OH}$ concentration of $1.5 \times 10^{7}$ molecules $\mathrm{cm}^{-3}$ around noon in summer in the Pearl River Delta, China (Hofzumahaus et al., 2009). The $\mathrm{OH}$ exposure in this study is only $5 \times 10^{6}$ molecules $\mathrm{cm}^{-3} \mathrm{~h}$, equivalent to $0.3 \mathrm{~h}$ of atmospheric oxidation. Therefore, the real-world SOA production factor from LDGVs in the atmosphere in China may be even higher than our estimation.

\subsection{SOA yield}

Effective SOA yield from vehicle exhaust calculated as described in Sect. 2.4.3 ranged from 2.8 to $17.2 \%$. Pankow (1994a, b) and Odum et al. (1996) indicated that $Y$ is a function of $M_{0}$ and the relation is described as

$Y=M_{0} \sum\left(\frac{\alpha_{i} K_{\mathrm{om}, i}}{1+K_{\mathrm{om}, i} M_{0}}\right)$,

where $K_{\mathrm{om}, i}$ and $\alpha_{i}$ are the mass-based absorption equilibrium partitioning coefficient and stoichiometric coefficient of product $i$, respectively; $M_{0}$ is the total mass concentration of organic material. As shown in Table 3, SOA yields for the Euro 1 vehicle were around 3\%, quite lower than 10-17\% for the Euro 4 vehicle. The mass fraction of aromatic hydrocarbons for the Euro 4 vehicle was about 2 times higher than that for the Euro 1 vehicle (Fig. 2a), which would form more semi-volatile organic compounds (SVOCs) partitioning into particle phase under similar $\mathrm{OH}$ exposure and thus lead to the relatively higher SOA yields.

Comparison of effective yield data obtained for the LDGV exhaust in this study with those of Nordin et al. (2013) is shown in Fig. 4. Effective yield data of this study are well fit with the one-product model, namely $Y=M_{0}\left(\frac{\alpha_{1} K_{\mathrm{om}, 1}}{1+K_{\mathrm{om}}, 1 M_{0}}\right)$. The appropriate values for $\alpha_{1}$ and $K_{\mathrm{om}, 1}$ when fitting the yields are $0.350 \pm 0.114$ and $0.007 \pm 0.004$, respectively. The effective SOA yields in the study of Nordin et al. (2013) were $60-360 \%$ higher than those in this study at the same concentrations of $\mathrm{M}_{0}$. In their calculation of the reacted SOA precursors, $C_{4}$-benzene and naphthalene were excluded. The effective SOA yields would increase $7-34 \%$ when $C_{4}$ benzene and naphthalene were excluded in this study, which could explain a small portion of the discrepancy. According to the estimation above, the loss of VOCs in the transfer lines was less than $5 \%$. A little higher than VOCs, if assumed to be $20 \%$, losses of intermediate volatility organic compounds (IVOCs) and SVOCs in the transfer lines would increase the SOA effective yields by a factor of $2-10 \%$ when the unexplained SOA discussed later was all attributed to the contribution from IVOCs and SVOCs. The existence of seed particles in the study of Nordin et al. (2013) might reduce the wall loss of semi-volatile organic vapors and thus increase the effective SOA yield (Kroll et al., 2007; Zhang et al., 2014; X. Zhang et al., 2015). However, Cocker III

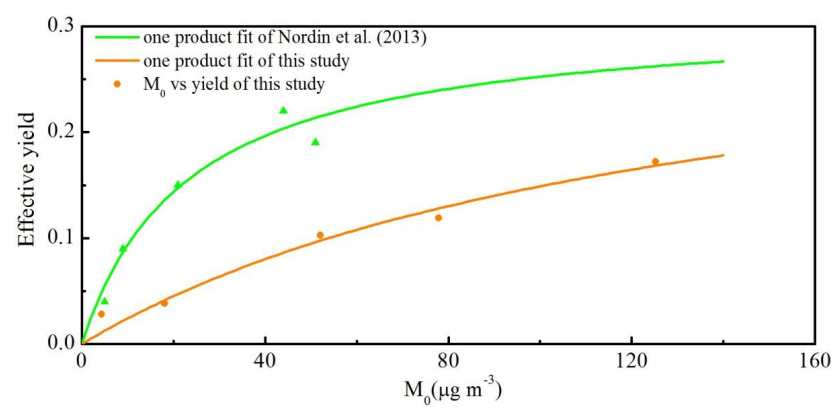

Figure 4. Comparison of yield data obtained for the gasoline experiments in this study with that of Nordin et al. (2013). The green line is the best fit one-product model $\left(\alpha_{1}=0.311, K_{\mathrm{om}, 1}=0.043\right)$ for the data set of Nordin et al. (2013). The orange line is the best one-product fit to the effective SOA yield in this study $\left(\alpha_{1}=0.350\right.$, $\left.K_{\text {om, } 1}=0.007\right)$. Organic precursors in the calculation of effective yields included benzene, toluene, $C_{2}$-benzene, $C_{3}$-benzene, $C_{4}$ benzene and naphthalene.

et al. (2001) found that SOA formation from $m$-xylene and 1,3,5-trimethylbenzene photo-oxidation was unaffected by the presence of ammonium sulfate seed aerosols. The influence of seed particles on SOA yields still needs further investigations. Faster oxidation rates caused by higher $\mathrm{OH}$ concentrations in the study of Nordin et al. (2013) would also result in higher SOA yields (Ng et al., 2007). Additionally, the different VOC profiles of exhausts might also influence the SOA yields.

SOA production from the reacted organic precursors can be estimated by the following formula:

$\Delta \mathrm{SOA}_{\text {predicted }}=\sum_{j}\left(\Delta X_{j} \times Y_{j}\right)$,

where $\triangle \mathrm{SOA}_{\text {predicted }}$ is the predicted SOA concentration (in $\left.\mu \mathrm{g} \mathrm{m}^{-3}\right) ; \Delta X_{j}$ is the mass of reacted aromatic hydrocarbon $X_{j}$ (in $\mu \mathrm{g} \mathrm{m}^{-3}$ ); and $Y_{j}$ is the corresponding SOA yield of $X_{j}$. In this study, the SOA yield of benzene and other single-ring aromatics were estimated using the two-product model curves taken from Borrás et al. (2012) and Odum et al. (1997), respectively. While the SOA yield of naphthalene was taken from Shakya et al. (2010). SOA yield curves of toluene and $m$-xylene from $\mathrm{Ng}$ et al. (2007) were also widely used to estimate SOA production (Platt et al., 2013). However, the introduction of seed aerosols and $\mathrm{OH}$ precursor made the SOA yield curves in the study of $\mathrm{Ng}$ et al. (2007) not suitable for this study. Considering that the study of Odum et al. (1997) provided a systematic estimation of SOA yields from toluene, $C_{2}$-benzene, $C_{3}$-benzene and $C_{4}$-benzene, we mainly used the two-product curves from Odum et al. (1997) to estimate the SOA production. The aerosol yield curves from the literature were converted to the same aerosol density of $1.4 \mathrm{~g} \mathrm{~cm}^{-3}$ in this study. The SOA yield for each precursor was calculated for the measured con- 


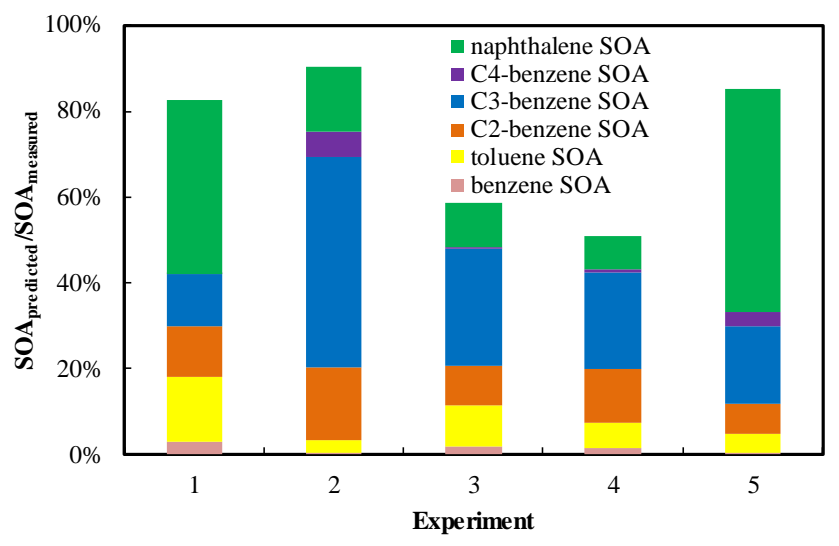

Figure 5. Contributions of the predicted benzene SOA, toluene SOA, $C_{2}$-benzene SOA, $C_{3}$-benzene SOA, $C_{4}$-benzene SOA and naphthalene SOA to the total formed SOA in all experiments.

centration of OA in the reactor. Then, the predicted SOA production from each precursor can be calculated (Table S2).

Figure 5 shows the contributions of the predicted benzene SOA, toluene SOA, $C_{2}$-benzene SOA, $C_{3}$-benzene SOA, $C_{4}$ benzene SOA and naphthalene SOA to the total measured SOA in all experiments. $C_{4}$-benzene contributed negligible SOA because of the very low emissions of $C_{4}$-benzene from light-duty gasoline vehicles (Fig. 2b). Though benzene accounted for a relatively higher percentage of the total VOCs, benzene also accounted for a negligible proportion of the formed SOA due to its low reactivity with $\mathrm{OH}$ radicals. Naphthalene was previously estimated to contribute around $5 \%$ of the vehicle SOA mass (Nordin et al., 2013). While in this study naphthalene was calculated to contribute $8-52 \%$ of the formed SOA. The initial concentrations of naphthalene in this study ranged from 8.5 to $39.5 \mathrm{ppb}$, much higher than $2.8-4.4 \mathrm{ppb}$ in the study of Nordin et al. (2013). The high contributions of naphthalene are probably attributed to its relatively higher initial concentrations and higher mass yield than single-ring aromatics for similar experimental conditions (Odum et al., 1997; Ng et al., 2007).

In total, single-ring aromatics and naphthalene accounted for $51-90 \%$ of the measured SOA, comparable to the estimation that classical C6-C9 light aromatics were responsible for $60 \%$ of the formed SOA from gasoline vehicle exhausts (Nordin et al., 2013), indicating that there are other SOA precursors in the LDGV exhausts. Platt et al. (2013) attributed the unexplained SOA formed from the aging of emissions from a Euro 5 gasoline car to highly oxygenated hydrocarbons. In addition, IVOCs such as branched and cyclic alkanes were recognized as important SOA precursors derived from wood burning, diesel engine and aircraft exhaust (Robinson et al., 2007; Weitkamp et al., 2007; Grieshop et al., 2009; Tkacik et al., 2012). Gordon et al. (2014) found that unspeciated species including branched and cyclic alkanes contributed about $30 \%$ of the nonmethane organic gas emissions
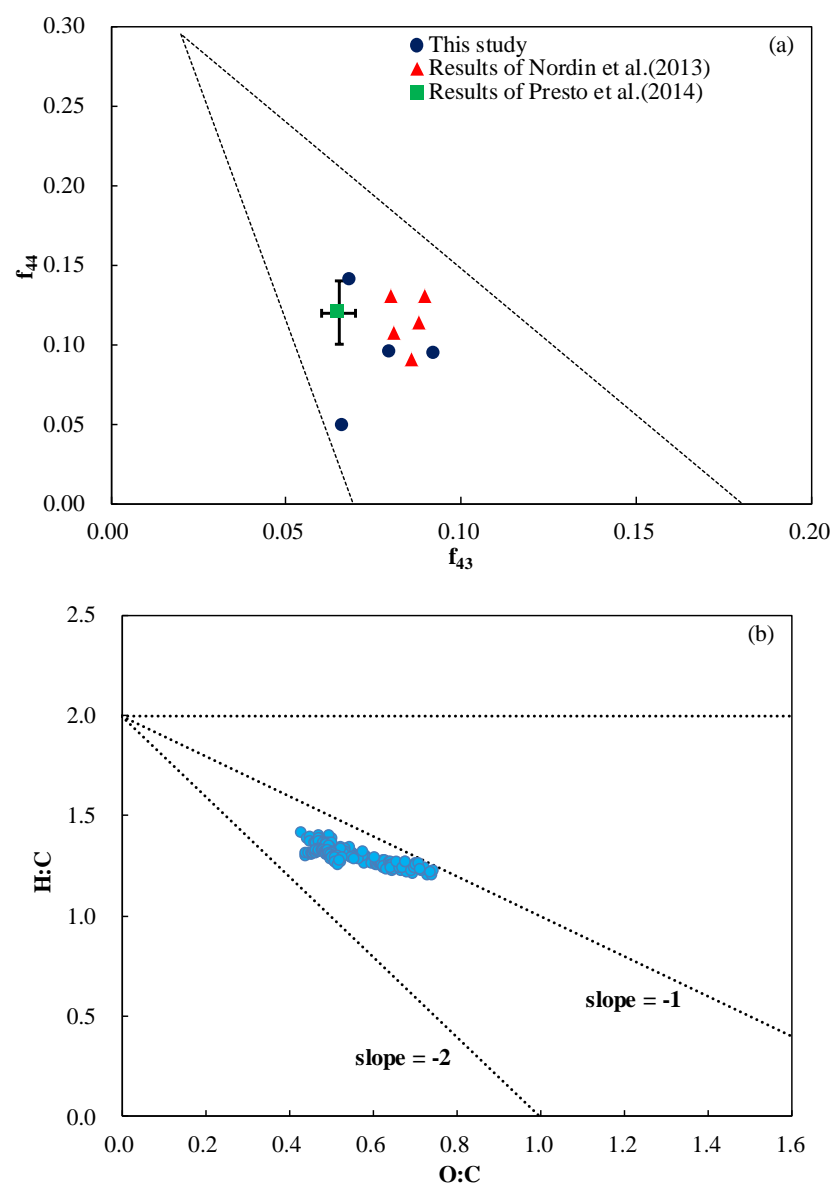

Figure 6. (a) The fractions of total organic signal at $m / z 43\left(f_{43}\right)$ vs. $m / z\left(f_{44}\right)$ at the end of each experiment together with the triangle plot of $\mathrm{Ng}$ et al. (2010). The solid square and triangles represent the results of Presto et al. (2014) and Nordin et al. (2013), respectively. The dotted lines define the space where ambient OOA components fall. The ranges of $f_{44}$ observed for SV-OOA and LV-OOA components are 0.03-0.11 and 0.13-0.21, respectively. (b) Van Krevelen diagram of SOA from light-duty gasoline vehicle exhaust. Dotted lines are to show slopes of $0,-1$ and -2 . AMS data of the experiment 5 were unavailable.

from LDGVs with model years of 1995 or later and are associated with the majority of the SOA formation. Tkacik et al. (2014) also found that unspeciated species were predicted to contribute twice as much SOA from in-use vehicle emissions as traditional precursors. It is worth noting that photooxidation of aromatic hydrocarbons in a complex mixture such as gasoline vehicle exhausts might alter the SOA yield compared to pure precursor experiments, thus, probably influencing the estimation in this study (Song et al., 2007). Wall losses of organic vapors were not considered in this study, which would lead to the underestimation of SOA production. Therefore, the mass closure analysis estimated the maximum amount of SOA that could be explained by aromatics. 


\subsection{SOA composition}

Fragmentations derived from the AMS data have been widely used to explore the oxidation degree of the organic aerosols (Zhang et al., 2005; Ng et al., 2010; Heald et al., 2010). The usually used ion fragments include $m / z 43,44$ and 57 . The dominating organic peaks in gasoline vehicle exhaust SOA are $m / z 43$ and 44 (Nordin et al., 2013), while $m / z 57$ is a main hydrocarbon fragment in diesel SOA (Chirico et al., 2010). Here, we use the approach of $\mathrm{Ng}$ et al. (2010) by plotting the fractions of total organic signal at $m / z 43\left(f_{43}\right)$ vs. $m / z 44\left(f_{44}\right)$ together with the triangle defined according to the analysis of ambient AMS data. The $m / z 43 \mathrm{sig}$ nal includes $\mathrm{C}_{3} \mathrm{H}_{7}^{+}$and $\mathrm{C}_{2} \mathrm{H}_{3} \mathrm{O}^{+}$ions, indicating fresh lessoxidized organic aerosols. The $\mathrm{m} / z 44$ signal, dominated by $\mathrm{CO}_{2}^{+}$and formed from the thermal decarboxylation of organic acids, is an indicator of highly oxygenated organic aerosols (Ng et al., 2010).

Figure 6a shows the $f_{43}$ vs. $f_{44}$ at the end of each experiment and the results of Nordin et al. (2013) and Presto et al. (2014), together with the triangle developed by $\mathrm{Ng}$ et al. (2010). The ambient low-volatility oxygenated OA (LVOOA) and semi-volatile OOA (SV-OOA) factors fall in the upper and lower portions of the triangle, respectively. Our data mainly lie in the SV-OOA region, similar to the results of Nordin et al. (2013) and Presto et al. (2014). However, SOA in one experiment shows relatively lower oxidation degree. This phenomenon reflects the different SOA compositions among different experiments and might be caused by the different VOCs profiles, $\mathrm{OH}$ exposure and organic mass loadings ( $\mathrm{Ng}$ et al., 2010).

The $\mathrm{O}: \mathrm{C}$ ratio can also be used to characterize the oxidation degree of the organic aerosols. After $5 \mathrm{~h}$ of irradiation the $\mathrm{H}: \mathrm{C}$ ratios varied from 1.22 to 1.37 and the $\mathrm{O}: \mathrm{C}$ ratios from 0.43 to 0.69 for all the experiments. Almost all the $\mathrm{O}: \mathrm{C}$ values were lower than 0.6 , comparable to the $\mathrm{SV}$ OOA compounds, which typically have $\mathrm{O}: \mathrm{C}$ ratios between 0.3 and 0.6 (Jimenez et al., 2009). Platt et al. (2013) observed a relatively higher $\mathrm{O}: \mathrm{C}$ ratio of 0.7 on the aging $\left(\mathrm{OH}=12 \times 10^{6}\right.$ molecules $\left.\mathrm{cm}^{-3} \mathrm{~h}\right)$ of emissions from a Euro 5 gasoline car operated during a New European Driving Cycle. As a higher $\mathrm{OH}$ exposure will lead to a higher $\mathrm{O}: \mathrm{C}$ ratio, if the gasoline exhaust in this study was irradiated under a similar OH exposure to that of Platt et al. (2013), the O : C ratios might reach the similar level or higher, comparable to the LV-OOA factor (Jimenez et al., 2009).

In Fig. 6b we plot the $\mathrm{O}: \mathrm{C}$ and $\mathrm{H}: \mathrm{C}$ molar ratios after SOA was formed during experiments 1,2 and 3 on a Van Krevelen diagram (Heald et al., 2010). The slopes ranged from -0.59 to -0.36 , similar to previous laboratory studies of Tkacik et al. (2012) for cyclic, linear and branched alkanes, Jathar et al. (2013) for unburned fuel and Presto et al. (2014) for light-duty gasoline vehicle exhaust. They are also similar to the ambient data (Ng et al., 2011). A slope of $-1,-0.5$ and 0 in the Van Krevelen diagram represents the addition of alcohol/peroxide, the addition of carboxylic acid with fragmentation, and the addition of carboxylic acid without fragmentation, respectively (Heald et al., 2010; Ng et al., 2011). Consequently, the slopes in this study indicate that the SOA formation is a combination of the addition of both carboxylic acid and alcohol/peroxide function groups without $\mathrm{C}-\mathrm{C}$ bond cleavage and/or the addition of carboxylic acid with $\mathrm{C}-\mathrm{C}$ bond breakage (Heald et al., 2010; $\mathrm{Ng}$ et al., 2011).

\section{The Supplement related to this article is available online at doi:10.5194/acp-15-9049-2015-supplement.}

Acknowledgements. This study was supported by National Natural Science Foundation of China (project no. 41025012/41121063), Strategic Priority Research Program of the Chinese Academy of Sciences (grant no. XDB05010200), NSFC-Guangdong Joint Funds (U0833003) and the Guangzhou Institute of Geochemistry (GIGCAS 135 project Y234161001).

Edited by: J. Allan

\section{References}

Aiken, A. C., DeCarlo, P. F., and Jimenez, J. L.: Elemental Analysis of Organic Species with Electron Ionization HighResolution Mass Spectrometry, Anal. Chem., 79, 8350-8358, doi:10.1021/ac071150w, 2007.

Aiken, A. C., DeCarlo, P. F., Kroll, J. H., Worsnop, D. R., Huffman, J. A., Docherty, K. S., Ulbrich, I. M., Mohr, C., Kimmel, J. R., Sueper, D., Sun, Y., Zhang, Q., Trimborn, A., Northway, M., Ziemann, P. J., Canagaratna, M. R., Onasch, T. B., Alfarra, M. R., Prevot, A. S. H., Dommen, J., Duplissy, J., Metzger, A., Baltensperger, U., and Jimenez, J. L.: O/C and OM/OC ratios of primary, secondary, and ambient organic aerosols with highresolution time-of-flight aerosol mass spectrometry, Environ. Sci. Technol., 42, 4478-4485, doi:10.1021/es703009q, 2008.

Borrás, E. and Tortajada-Genaro, L. A.: Secondary organic aerosol formation from the photo-oxidation of benzene, Atmos. Environ., 47, 154-163, 2012.

Cao, J. J., Lee, S. C., Ho, K. F., Zhang, X. Y., Zou, S. C., Fung, K. Chow, J. C., and Watson, J. G.: Characteristics of carbonaceous aerosol in Pearl River Delta Region, China during 2001 winter period, Atmos. Environ., 37, 1451-1460, doi:10.1016/S13522310(02)01002-6, 2003.

Chan, C. K. and Yao, X.: Air pollution in mega cities in China, Atmos. Environ., 42, 1-42, doi:10.1016/j.atmosenv.2007.09.003, 2008.

Chirico, R., DeCarlo, P. F., Heringa, M. F., Tritscher, T., Richter, R., Prévôt, A. S. H., Dommen, J., Weingartner, E., Wehrle, G., Gysel, M., Laborde, M., and Baltensperger, U.: Impact of aftertreatment devices on primary emissions and secondary organic aerosol formation potential from in-use diesel vehicles: results from smog chamber experiments, Atmos. Chem. Phys., 10, 11545-11563, doi:10.5194/acp-10-11545-2010, 2010. 
Clairotte, M., Adam, T. W., Zardini, A. A., Manfredi, U., Martini, G., Krasenbrink, A., Vicet, A., Tournie, E., and Astorga, C.: Effects of low temperature on the cold start gaseous emissions from light duty vehicles fuelled by ethanol-blended gasoline, Appl. Energ., 102, 44-54, 2013.

Cocker III, D. R., Mader, B. T., Kalberer, M., Flagan, R. C., and Seinfeld, J. H.: The effect of water on gas-particle partitioning of secondary organic aerosol: II. m-xylene and 1,3,5trimethylbenzene photooxidation systems, Atmos. Environ., 35, 6073-6085, doi:10.1016/S1352-2310(01)00405-8, 2001.

DeCarlo, P. F., Kimmel, J. R., Trimborn, A., Northway, M. J., Jayne, J. T., Aiken, A. C., Gonin, M., Fuhrer, K., Horvath, T., Docherty, K. S., Worsnop, D. R., and Jimenez, J. L.: Field-Deployable, High-Resolution, Time-of-Flight Aerosol Mass Spectrometer, Anal. Chem., 78, 8281-8289, doi:10.1021/ac061249n, 2006.

de Gouw, J. A., Middlebrook, A. M., Warneke, C., Goldan, P. D., Kuster, W. C., Roberts, J. M., Fehsenfeld, F. C., Worsnop, D. R., Canagaratna, M. R., Pszenny, A. A. P., Keene, W. C., Marchewka, M., Bertman, S. B., and Bates, T. S.: Budget of organic carbon in a polluted atmosphere: Results from the New England Air Quality Study in 2002, J. Geophys. Res., 110, D16305, doi:10.1029/2004JD005623, 2005.

Donahue, N. M., Robinson, A. L., Stanier, C. O., and Pandis, S. N.: Coupled partitioning, dilution, and chemical aging of semivolatile organics, Environ. Sci. Technol., 40, 2635-2643, doi:10.1021/es052297c, 2006.

Donahue, N. M., Robinson, A. L., and Pandis, S. N.: Atmospheric organic particulate matter: From smoke to secondary organic aerosol, Atmos. Environ., 43, 94-106, doi:10.1016/j.atmosenv.2008.09.055, 2009.

Duan, F. K., He, K. B., Ma, Y. L., Jia, Y. T., Yang, F. M., Lei, Y., Tanaka, S., and Okuta, T.: Characteristics of carbonaceous aerosols in Beijing, China, Chemosphere, 60, 355-364, doi:10.1016/j.chemosphere.2004.12.035, 2005.

Duan, F. K., Liu, X. D., He, K. B., Li, Y. W., and Dong, S. P.: Characteristics and source identification of particulate matter in wintertime in Beijing, Water Air Soil Poll., 180, 171-183, doi:10.1007/s11270-006-9261-4, 2007.

Gentner, D. R., Worton, D. R., Isaacman, G., Davis, L. C., Dallmann, T. R., Wood, E. C., Herndon, S. C., Goldstein, A. H., and Harley, R. A.: Chemical Composition of Gas-Phase Organic Carbon Emissions from Motor Vehicles and Implications for Ozone Production, Environ. Sci. Technol., 47, 11837-11848, doi:10.1021/es401470e, 2013.

Gordon, T. D., Presto, A. A., May, A. A., Nguyen, N. T., Lipsky, E. M., Donahue, N. M., Gutierrez, A., Zhang, M., Maddox, C., Rieger, P., Chattopadhyay, S., Maldonado, H., Maricq, M. M., and Robinson, A. L.: Secondary organic aerosol formation exceeds primary particulate matter emissions for lightduty gasoline vehicles, Atmos. Chem. Phys., 14, 4661-4678, doi:10.5194/acp-14-4661-2014, 2014.

Gormley, P. G. and Kennedy, M.: Diffusion from a Stream Flowing through a Cylindrical Tube, Proc. R. Ir. Acad. S. A.-M., 52, 163169, 1949.

Grieshop, A. P., Logue, J. M., Donahue, N. M., and Robinson, A. L.: Laboratory investigation of photochemical oxidation of organic aerosol from wood fires 1: measurement and simulation of organic aerosol evolution, Atmos. Chem. Phys., 9, 1263-1277, doi:10.5194/acp-9-1263-2009, 2009.
Guo, H., Zou, S. C., Tsai, W. Y., Chan, L. Y., and Blake, D. R.: Emission characteristics of nonmethane hydrocarbons from private cars and taxis at different driving speeds in Hong Kong, Atmos. Environ., 45, 2711-2721, doi:10.1016/j.atmosenv.2011.02.053, 2011.

Hagler, G. S., Bergin, M. H., Salmon, L. G., Yu, J. Z., Wan, E. C. H., Zheng, M., Zeng, L. M., Kiang, C. S., Zhang, Y. H., Lau, A. K. H., and Schauer, J. J.: Source areas and chemical composition of fine particulate matter in the Pearl River Delta region of China, Atmos. Environ., 40, 3802-3815, doi:10.1016/j.atmosenv.2006.02.032, 2006.

Hallquist, M., Wenger, J. C., Baltensperger, U., Rudich, Y., Simpson, D., Claeys, M., Dommen, J., Donahue, N. M., George, C., Goldstein, A. H., Hamilton, J. F., Herrmann, H., Hoffmann, T., Iinuma, Y., Jang, M., Jenkin, M. E., Jimenez, J. L., Kiendler-Scharr, A., Maenhaut, W., McFiggans, G., Mentel, Th. F., Monod, A., Prévôt, A. S. H., Seinfeld, J. H., Surratt, J. D., Szmigielski, R., and Wildt, J.: The formation, properties and impact of secondary organic aerosol: current and emerging issues, Atmos. Chem. Phys., 9, 5155-5236, doi:10.5194/acp-9-51552009, 2009.

He, K., Yang, F., Ma, Y., Zhang, Q., Yao, X., Chan, C. K., Cadle, S., Chan, T., and Mulawa, P.: The characteristics of $\mathrm{PM}_{2.5}$ in Beijing, China, Atmos. Environ., 35, 4959-4970, doi:10.1016/S1352-2310(01)00301-6, 2001.

Heald, C. L., Jacob, D. J., Park, R. J., Russell, L. M., Huebert, B. J., Seinfeld, J. H., Liao, H., and Weber, R. J.: A large organic aerosol source in the free troposphere missing from current models, Geophys. Res. Lett., 32, L18809, doi:10.1029/2005GL023831, 2005.

Heald, C. L., Kroll, J. H., Jimenez, J. L., Docherty, K. S., DeCarlo, P. F., Aiken, A. C., Chen, Q., Martin, S. T., Farmer, D. K., and Artaxo, P.: A simplified description of the evolution of organic aerosol composition in the atmosphere, Geophys. Res. Lett., 37, L08803, doi:10.1029/2010g1042737, 2010.

Henry, K. M., Lohaus, T., and Donahue, N. M.: Organic Aerosol Yields from $\alpha$-Pinene Oxidation: Bridging the Gap between First-Generation Yields and Aging Chemistry, Environ. Sci. Technol., 46, 12347-12354, doi:10.1021/es302060y, 2012.

Hildebrandt, L., Donahue, N. M., and Pandis, S. N.: High formation of secondary organic aerosol from the photo-oxidation of toluene, Atmos. Chem. Phys., 9, 2973-2986, doi:10.5194/acp-92973-2009, 2009.

Hofzumahaus, A., Rohrer, F., Lu, K., Bohn, B., Brauers, T., Chang, C.-C., Fuchs, H., Holland, F., Kita, K., Kondo, Y., Li, X., Lou, S., Shao, M., Zeng, L., Wahner, A., and Zhang, Y.: Amplified Trace Gas Removal in the Troposphere, Science, 324, 17021704, doi:10.1126/science.1164566, 2009.

Huang, C., Lou, D. M., Hu, Z. Y., Feng, Q., Chen, Y. R., Chen, C. H., Tan, P. Q., and Yao, D.: A PEMS study of the emissions of gaseous pollutants and ultrafine particles from gasoline- and diesel-fueled vehicles, Atmos. Environ., 77, 703710, doi:10.1016/j.atmosenv.2013.05.059, 2013.

Huang, C., Wang, H. L., Li, L., Wang, Q., Lu, Q., de Gouw, J. A., Zhou, M., Jing, S. A., Lu, J., and Chen, C. H.: VOC species and emission inventory from vehicles and their SOA formation potentials estimation in Shanghai, China, Atmos. Chem. Phys. Discuss., 15, 7977-8015, doi:10.5194/acpd-15-7977-2015, 2015.

Huo, H., Yao, Z., Zhang, Y., Shen, X., Zhang, Q., Ding, Y., and He, $\mathrm{K}$.: On-board measurements of emissions from light-duty gaso- 
line vehicles in three mega-cities of China, Atmos. Environ., 49, 371-377, doi:10.1016/j.atmosenv.2011.11.005, 2012.

Jathar, S. H., Miracolo, M. A., Tkacik, D. S., Donahue, N. M., Adams, P. J., and Robinson, A. L.: Secondary Organic Aerosol Formation from Photo-Oxidation of Unburned Fuel: Experimental Results and Implications for Aerosol Formation from Combustion Emissions, Environ. Sci. Technol., 47, 12886-12893, doi:10.1021/es403445q, 2013.

Jayne, J. T., Leard, D. C., Zhang, X., Davidovits, P., Smith, K. A., Kolb, C. E., and Worsnop, D. R.: Development of an Aerosol Mass Spectrometer for Size and Composition Analysis of Submicron Particles, Aerosol. Sci. Tech., 33, 49-70, doi:10.1080/027868200410840, 2000.

Jimenez, J. L., Canagaratna, M. R., Donahue, N. M., Prevot, A. S. H., Zhang, Q., Kroll, J. H., DeCarlo, P. F., Allan, J. D., Coe, H., Ng, N. L., Aiken, A. C., Docherty, K. S., Ulbrich, I. M., Grieshop, A. P., Robinson, A. L., Duplissy, J., Smith, J. D., Wilson, K. R., Lanz, V. A., Hueglin, C., Sun, Y. L., Tian, J., Laaksonen, A., Raatikainen, T., Rautiainen, J., Vaattovaara, P., Ehn, M., Kulmala, M., Tomlinson, J. M., Collins, D. R., Cubison, M. J., E., Dunlea, J., Huffman, J. A., Onasch, T. B., Alfarra, M. R., Williams, P. I., Bower, K., Kondo, Y., Schneider, J., Drewnick, F., Borrmann, S., Weimer, S., Demerjian, K., Salcedo, D., Cottrell, L., Griffin, R., Takami, A., Miyoshi, T., Hatakeyama, S., Shimono, A., Sun, J. Y., Zhang, Y. M., Dzepina, K., Kimmel, J. R., Sueper, D., Jayne, J. T., Herndon, S. C., Trimborn, A. M., Williams, L. R., Wood, E. C., Middlebrook, A. M., Kolb, C. E., Baltensperger, U., and Worsnop, D. R.: Evolution of Organic Aerosols in the Atmosphere, Science, 326, 1525-1529, doi:10.1126/science.1180353, 2009.

Johnson, D., Utembe, S. R., Jenkin, M. E., Derwent, R. G., Hayman, G. D., Alfarra, M. R., Coe, H., and McFiggans, G.: Simulating regional scale secondary organic aerosol formation during the TORCH 2003 campaign in the southern UK, Atmos. Chem. Phys., 6, 403-418, doi:10.5194/acp-6-403-2006, 2006.

Jordan, A., Haidacher, S., Hanel, G., Hartungen, E., Mark, L., Seehauser, H., Schottkowsky, R., Sulzer, P., and Mark, T. D.: A high resolution and high sensitivity proton-transfer-reaction time-offlight mass spectrometer (PTR-TOF-MS), Int. J. Mass Spectrom., 286, 122-128, 2009.

Kanakidou, M., Seinfeld, J. H., Pandis, S. N., Barnes, I., Dentener, F. J., Facchini, M. C., Van Dingenen, R., Ervens, B., Nenes, A., Nielsen, C. J., Swietlicki, E., Putaud, J. P., Balkanski, Y., Fuzzi, S., Horth, J., Moortgat, G. K., Winterhalter, R., Myhre, C. E. L., Tsigaridis, K., Vignati, E., Stephanou, E. G., and Wilson, J.: Organic aerosol and global climate modelling: a review, Atmos. Chem. Phys., 5, 1053-1123, doi:10.5194/acp-5-1053-2005, 2005.

Kirchstetter, T. W., Harley, R. A., Kreisberg, N. M., Stolzenburg, M. R., and Hering, S. V.: On-road measurement of fine particle and nitrogen oxide emissions from light- and heavy-duty motor vehicles, Atmos. Environ., 33, 2955-2968, doi:10.1016/S13522310(99)00089-8, 1999.

Kroll, J. H., Chan, A. W. H., Ng, N. L., Flagan, R. C., and Seinfeld, J. H.: Reactions of Semivolatile Organics and Their Effects on Secondary Organic Aerosol Formation, Environ. Sci. Technol., 41, 3545-3550, doi:10.1021/es062059x, 2007.

Kroll, J. H., Smith, J. D., Worsnop, D. R., and Wilson, K. R.: Characterisation of lightly oxidised organic aerosol formed from the photochemical aging of diesel exhaust particles, Environ. Chem., 9, 211-220, doi:10.1071/EN11162, 2012.

Lindinger, W., Hansel, A., and Jordan, A.: On-line monitoring of volatile organic compounds at pptv levels by means of protontransfer-reaction mass spectrometry (PTR-MS) medical applications, food control and environmental research, Int. J. Mass Spectrom., 173, 191-241, doi:10.1016/S0168-1176(97)00281-4, 1998.

Liu, P. S. K., Deng, R., Smith, K. A., Williams, L. R., Jayne, J. T., Canagaratna, M. R., Moore, K., Onasch, T. B., Worsnop, D. R., and Deshler, T.: Transmission Efficiency of an Aerodynamic Focusing Lens System: Comparison of Model Calculations and Laboratory Measurements for the Aerodyne Aerosol Mass Spectrometer, Aerosol. Sci. Tech., 41, 721-733, doi:10.1080/02786820701422278, 2007.

Liu, T. Y., Wang, X. M., Wang, B. G., Ding, X., Deng, W., Lü, S. J., and Zhang, Y. L.: Emission factor of ammonia $\left(\mathrm{NH}_{3}\right)$ from on-road vehicles in China: tunnel tests in urban Guangzhou, Environ. Res. Lett., 9, 064027, doi:10.1088/1748-9326/9/6/064027, 2014.

McMurry, P. H. and Grosjean, D.: Gas and aerosol wall losses in Teflon film smog chambers, Environ. Sci. Technol., 19, 11761182, doi:10.1021/es00142a006, 1985.

Miracolo, M. A., Presto, A. A., Lambe, A. T., Hennigan, C. J., Donahue, N. M., Kroll, J. H., Worsnop, D. R., and Robinson, A. L.: Photo-oxidation of low-volatility organics found in motor vehicle emissions: Production and chemical evolution of organic aerosol mass, Environ. Sci. Technol., 44, 1638-1643, doi:10.1021/es902635c, 2010.

Nakao, S., Shrivastava, M., Nguyen, A., Jung, H., and Cocker, D.: Interpretation of Secondary Organic Aerosol Formation from Diesel Exhaust Photooxidation in an Environmental Chamber, Aerosol. Sci. Tech., 45, 964-972, doi:10.1080/02786826.2011.573510, 2011.

NBSC National Bureau of Statistics of China: China Statistical Yearbook, Beijing, China Statistics Press, 2013.

Ng, N. L., Kroll, J. H., Chan, A. W. H., Chhabra, P. S., Flagan, R. C., and Seinfeld, J. H.: Secondary organic aerosol formation from $m$-xylene, toluene, and benzene, Atmos. Chem. Phys., 7, 3909-3922, doi:10.5194/acp-7-3909-2007, 2007.

Ng, N. L., Canagaratna, M. R., Zhang, Q., Jimenez, J. L., Tian, J., Ulbrich, I. M., Kroll, J. H., Docherty, K. S., Chhabra, P. S., Bahreini, R., Murphy, S. M., Seinfeld, J. H., Hildebrandt, L., Donahue, N. M., DeCarlo, P. F., Lanz, V. A., Prévôt, A. S. H., Dinar, E., Rudich, Y., and Worsnop, D. R.: Organic aerosol components observed in Northern Hemispheric datasets from Aerosol Mass Spectrometry, Atmos. Chem. Phys., 10, 46254641, doi:10.5194/acp-10-4625-2010, 2010.

Ng, N. L., Canagaratna, M. R., Jimenez, J. L., Chhabra, P. S., Seinfeld, J. H., and Worsnop, D. R.: Changes in organic aerosol composition with aging inferred from aerosol mass spectra, Atmos. Chem. Phys., 11, 6465-6474, doi:10.5194/acp-11-64652011, 2011.

Nordin, E. Z., Eriksson, A. C., Roldin, P., Nilsson, P. T., Carlsson, J. E., Kajos, M. K., Hellén, H., Wittbom, C., Rissler, J., Löndahl, J., Swietlicki, E., Svenningsson, B., Bohgard, M., Kulmala, M., Hallquist, M., and Pagels, J. H.: Secondary organic aerosol formation from idling gasoline passenger vehicle emissions investi- 
gated in a smog chamber, Atmos. Chem. Phys., 13, 6101-6116, doi:10.5194/acp-13-6101-2013, 2013.

Odum, J. R., Hoffmann, T., Bowman, F., Collins, D., Flagan, R. C., and Seinfeld, J. H.: Gas/particle partitioning and secondary organic aerosol yields, Environ. Sci. Technol., 30, 2580-2585, doi:10.1021/es950943+, 1996.

Odum, J. R., Jungkamp, T. P. W., Griffin, R. J., Forstner, H. J. L., Flagan, R. C., and Seinfeld, J. H.: Aromatics, reformulated gasoline, and atmospheric organic aerosol formation, Environ. Sci. Technol., 31, 1890-1897, doi:10.1021/es9605351, 1997.

Pankow, J. F.: An absorption-model of gas-particle partitioning of organic compounds in the atmosphere, Atmos. Environ., 28, 185-188, 1994a.

Pankow, J. F.: An absorption-model of the gas aerosol partitioning involved in the formation of secondary organic aerosol, Atmos. Environ., 28, 189-193, 1994b.

Pathak, R. K., Stanier, C. O., Donahue, N. M., and Pandis, S. N.: Ozonolysis of alpha-pinene at atmospherically relevant concentrations: Temperature dependence of aerosol mass fractions (yields), J. Geophys. Res.-Atmos., 112, D03201, doi:10.1029/2006jd007436, 2007.

Platt, S. M., El Haddad, I., Zardini, A. A., Clairotte, M., Astorga, C., Wolf, R., Slowik, J. G., Temime-Roussel, B., Marchand, N., Ježek, I., Drinovec, L., Mocnik, G., Möhler, O., Richter, R., Barmet, P., Bianchi, F., Baltensperger, U., and Prévôt, A. S. H.: Secondary organic aerosol formation from gasoline vehicle emissions in a new mobile environmental reaction chamber, Atmos. Chem. Phys., 13, 9141-9158, doi:10.5194/acp-13-91412013, 2013.

Presto, A. A., Gordon, T. D., and Robinson, A. L.: Primary to secondary organic aerosol: evolution of organic emissions from mobile combustion sources, Atmos. Chem. Phys., 14, 5015-5036, doi:10.5194/acp-14-5015-2014, 2014.

Robinson, A. L., Donahue, N. M., Shrivastava, M. K., Weitkamp, E. A., Sage, A. M., Grieshop, A. P., Lane, T. E., Pierce, J. R., and Pandis, S. N.: Rethinking Organic Aerosols: Semivolatile Emissions and Photochemical Aging, Science, 315, 1259-1262, doi:10.1126/science.1133061, 2007

Samy, S. and Zielinska, B.: Secondary organic aerosol production from modern diesel engine emissions, Atmos. Chem. Phys., 10, 609-625, doi:10.5194/acp-10-609-2010, 2010.

Saxena, P. and Hildemann, L.: Water-soluble organics in atmospheric particles: A critical review of the literature and application of thermodynamics to identify candidate compounds, J. Atmos. Chem., 24, 57-109, doi:10.1007/BF00053823, 1996.

Schauer, J. J., Kleeman, M. J., Cass, G. R., and Simoneit, B. R. T.: Measurement of emissions from air pollution sources. 5. C1-C32 organic compounds from gasolinepowered motor vehicles, Environ. Sci. Technol., 36, 1169-1180, doi:10.1021/es0108077, 2002.

Shakya, K. M. and Griffin, R. J.: Secondary organic aerosol from photooxidation of polycyclic aromatic hydrocarbons, Environ. Sci. Technol., 44, 8134-8139, doi:10.1021/es1019417, 2010.

Song, C., Na, K., Warren, B., Malloy, Q., and Cocker, D. R.: Impact of Propene on Secondary Organic Aerosol Formation from m-Xylene, Environ. Sci. Technol., 41, 6990-6995, doi:10.1021/es062279a, 2007.

Tkacik, D. S., Presto, A. A., Donahue, N. M., and Robinson, A. L.: Secondary organic aerosol formation from intermediate-volatility organic compounds: cyclic, linear, and branched alkanes, Environ. Sci. Technol., 46, 8773-8781, doi:10.1021/es301112c, 2012.

Tkacik, D. S., Lambe, A. T., Jathar, S., Li, X., Presto, A. A., Zhao, Y. L., Blake, D., Meinardi, S., Jayne, J. T., Croteau, P. L., and Robinson, A. L.: Secondary Organic Aerosol Formation from in-Use Motor Vehicle Emissions Using a Potential Aerosol Mass Reactor, Environ. Sci. Technol., 48, 11235-11242, doi:10.1021/es502239v, 2014.

Tong, H. Y., Hung, W. T., and Cheung, C. S.: On-road motor vehicle emissions and fuel consumption in urban driving conditions, J. Air Waste Manage., 50, 543-554, 2000.

Volkamer, R., Jimenez, J. L., San Martini, F., Dzepina, K., Zhang, Q., Salcedo, D., Molina, L. T., Worsnop, D. R., and Molina, M. J.: Secondary organic aerosol formation from anthropogenic air pollution: Rapid and higher than expected, Geophys. Res. Lett., 33, L17811, doi:10.1029/2006g1026899, 2006.

Wagner, D. V., An, F., and Wang, C.: Structure and impacts of fuel economy standards for passenger cars in China, Energ. Policy, 37, 3803-3811, doi:10.1016/j.enpol.2009.07.009, 2009.

Wang, J., Jin, L., Gao, J., Shi, J., Zhao, Y., Liu, S., Jin, T., Bai, Z., and $\mathrm{Wu}, \mathrm{C}$.-Y.: Investigation of speciated VOC in gasoline vehicular exhaust under ECE and EUDC test cycles, Sci. Total Environ., 445-446, 110-116, doi:10.1016/j.scitotenv.2012.12.044, 2013.

Wang, X., Liu, T., Bernard, F., Ding, X., Wen, S., Zhang, Y., Zhang, Z., He, Q., Lü, S., Chen, J., Saunders, S., and Yu, J.: Design and characterization of a smog chamber for studying gas-phase chemical mechanisms and aerosol formation, Atmos. Meas. Tech., 7, 301-313, doi:10.5194/amt-7-301-2014, 2014.

Wang, X. M. and Wu. T.: Release of isoprene and monoterpenes during the aerobic decomposition of orange wastes from laboratory incubation experiments, Environ. Sci. Technol., 42, 32653270, 2008.

Wehner, B., Wiedensohler, A., Tuch, T. M., Wu, Z. J., Hu, M., Slanina, J., and Kiang, C. S.: Variability of the aerosol number size distribution in Beijing, China: New particle formation, dust storms, and high continental background, Geophys. Res. Lett., 31, L22108, doi:10.1029/2004GL021596, 2004.

Weitkamp, E. A., Sage, A. M., Pierce, J. R., Donahue, N. M., and Robinson, A. L.: Organic aerosol formation from photochemical oxidation of diesel exhaust in a smog chamber, Environ. Sci. Technol., 41, 6969-6975, doi:10.1021/es070193r, 2007.

Yamamoto, Y., Kambe, Y., Yamada, H., and Tonokura, K.: Measurement of Volatile Organic Compounds in Vehicle Exhaust Using Single-Photon Ionization Time-of-Flight Mass Spectrometry, Anal. Sci., 28, 385-390, doi:10.2116/analsci.28.385, 2012.

Yang, H., Yu, J. Z., Ho, S. S. H., Xu, J. H., Wu, W. S., Wan, C. H., Wang, X. D., Wang, X. R., and Wang, L. S.: The chemical composition of inorganic and carbonaceous materials in $\mathrm{PM}_{2.5}$ in Nanjing, China, Atmos. Environ., 39, 3735-3749, doi:10.1016/j.atmosenv.2005.03.010, 2005.

Yi, Z., Wang, X., Sheng, G., Zhang, D., Zhou, G., and Fu, J.: Soil uptake of carbonyl sulfide in subtropical forests with different successional stages in south China, J. Geophys. Res., 112, D08302, doi:10.1029/2006JD008048, 2007.

Zhang, Q., Worsnop, D. R., Canagaratna, M. R., and Jimenez, J. L.: Hydrocarbon-like and oxygenated organic aerosols in Pittsburgh: insights into sources and processes of organic aerosols, 
Atmos. Chem. Phys., 5, 3289-3311, doi:10.5194/acp-5-32892005, 2005.

Zhang, Q., Jimenez, J. L., Canagaratna, M. R., Allan, J. D., Coe, H., Ulbrich, I., Alfarra, M. R., Takami, A., Middlebrook, A. M., Sun, Y. L., Dzepina, K., Dunlea, E., Docherty, K., DeCarlo, P. F., Salcedo, D., Onasch, T., Jayne, J. T., Miyoshi, T., Shimono, A., Hatakeyama, S., Takegawa, N., Kondo, Y., Schneider, J., Drewnick, F., Borrmann, S., Weimer, S., Demerjian, K., Williams, P., Bower, K., Bahreini, R., Cottrell, L., Griffin, R. J., Rautiainen, J., Sun, J. Y., Zhang, Y. M., and Worsnop, D. R.: Ubiquity and dominance of oxygenated species in organic aerosols in anthropogenically-influenced Northern Hemisphere midlatitudes, Geophys. Res. Lett., 34, L13801, doi:10.1029/2007g1029979, 2007.

Zhang, Q., He, K., and Huo, H.: Policy: Cleaning China's air, Nature, 484, 161-162, 2012.

Zhang, X., Cappa, C. D., Jathar, S. H., McVay, R. C., Ensberg, J. J., Kleeman, M. J., and Seinfeld, J. H.: Influence of vapor wall loss in laboratory chambers on yields of secondary organic aerosol, P. Natl. Acad. Sci. USA, 111, 5802-5807, doi:10.1073/pnas.1404727111, 2014.

Zhang, X., Schwantes, R. H., McVay, R. C., Lignell, H., Coggon, M. M., Flagan, R. C., and Seinfeld, J. H.: Vapor wall deposition in Teflon chambers, Atmos. Chem. Phys., 15, 4197-4214, doi:10.5194/acp-15-4197-2015, 2015.
Zhang, Y., Wang, X., Blake, D. R., Li, L., Zhang, Z., Wang, S., Guo, H., Lee, F. S. C., Gao, B., Chan, L., Wu, D., and Rowland, F. S.: Aromatic hydrocarbons as ozone precursors before and after outbreak of the 2008 financial crisis in the Pearl River Delta region, south China, J. Geophys. Res., 117, D15306, doi:10.1029/2011JD017356, 2012.

Zhang, Y., Wang, X., Zhang, Z., Lü, S., Shao, M., Lee, F. S. C., and Yu, J.: Species profiles and normalized reactivity of volatile organic compounds from gasoline evaporation in China, Atmos. Environ., 79, 110-118, doi:10.1016/j.atmosenv.2013.06.029, 2013.

Zhang, Y. L., Guo, H., Wang, X. M., Simpson, I. J., Barletta, B., Blake, D. R., Meinardi, S., Rowland, F. S., Cheng, H. R., Saunders, S. M., and Lam, S. H. M.: Emission patterns and spatiotemporal variations of halocarbons in the Pearl River Delta region, southern China, J. Geophys. Res., 115, D15309, doi:10.1029/2009JD013726, 2010.

Zhang, Y. L., Wang, X. M., Li, G. H., Yang, W. Q., Huang, Z. H., Zhang, Z., Huang, X. Y., Deng, W., Liu, T. Y., Huang, Z. Z., and Zhang, Z. Y.: Emission factors of fine particles, carbonaceous aerosols and traces gases from road vehicles: recent tests in an urban tunnel in the Pearl River Delta, China, Atmos. Environ., accepted, 2015. 